\title{
Storytelling of the Haggis. Construction, Narration and Negotiation of a Scottish National Symbol
}

\section{Francesco Buscemi}

\section{(2) OpenEdition \\ 1 Journals}

\section{Electronic version}

URL: http://journals.openedition.org/etudesecossaises/3749

DOI: 10.4000/etudesecossaises.3749

ISSN: 1969-6337

\section{Publisher}

UGA Éditions/Université Grenoble Alpes

\section{Printed version}

ISBN: 978-2-37747-275-8

ISSN: $1240-1439$

\section{Electronic reference}

Francesco Buscemi, "Storytelling of the Haggis. Construction, Narration and Negotiation of a Scottish National Symbol", Études écossaises [Online], 21 | 2021, Online since 31 March 2021, connection on 31 March 2021. URL: http://journals.openedition.org/etudesecossaises/3749 ; DOI: https://doi.org/ 10.4000/etudesecossaises.3749

This text was automatically generated on 31 March 2021.

(c) Études écossaises 


\title{
Storytelling of the Haggis. Construction, Narration and Negotiation of a Scottish National Symbol
}

\author{
Francesco Buscemi
}

\section{Introduction}

1 This article aims to analyse the way television and the internet have created or recirculated the haggis, a popular Scottish dish, linking it to feelings of national identity and elements of nation building. The haggis is a dish based on lamb's offal such as liver, lungs and heart, added to with onion, oatmeal, suet and various spices, and cooked in the sheep's stomach. It is considered the Scottish national dish (Balic, 2013) and even the glorious Scottish poet Robert Burns (1850) wrote a poem entirely dedicated to it, Address to a Haggis. Crofton (2014) argues that it was actually an English dish originating in fifteenth-century Lancashire, which arrived in Scotland after 1700. Today, the haggis is the dish traditionally concluding the feast of 25 January, which is "a de facto Scottish national day" (Balic, 2013, p. 82). During this day, people celebrate the haggis and the poet by reading the poem in what is called the Burns night or Burns supper. The haggis is thus intrinsically bound with the idea of Scotland as a nation and with sentiments of Scottish national identity.

2 When Scotland is associated with the concept of the nation, various issues very often arise, due to the status of Scotland within the nation-state of the UK. All of this becomes even more complex when we analyse Scotland's representation on TV, especially when the investigated channels broadcast on a national scale. These issues are central to this article, which starts by reviewing literature revolving around the concepts of the nation and national culture, their interrelations with TV and food, and Scotland in this complex scenario. 


\section{Existing literature}

\section{The nation and national culture}

Meinecke (1970) was one of the first scholars trying to systematise a broad theory of the nation. He pointed out that two kinds of nations exist: the Staatsnation, which is a military and political apparatus; and the Kulturnation, which relies on a shared language and common culture. Johnson finds that all this means that the nation may be considered "as a political construction or as "citizenship"' (1993, p. 181). However, Smith warns that "purely 'objective' criteria of the nation-language, religion, territory and so on-always fail to include some nations" (2010, p. 12).

4 Following on from Meinecke (1970), Guibernau (2007) argues that there are two approaches to the nation, primordialism and instrumentalism. Primordialists consider the nation as based on nature, tradition, beliefs and language; instrumentalists, by contrast, see it as something constructed by powerful elites. This has inspired postmodernists and deconstructionists, who argue that elites invent traditions that support their ideologies (Guibernau, 2007). The idea that the nation is totally constructed is present in the theory of the nation as an "imagined community" developed by Anderson (1983), which is generally mentioned as the first theorisation of the modern nation.

5 Anderson's idea is that the nation is a socially constructed concept, which is not natural at all, and that, importantly for this article, the media play a relevant role in this process. Anderson does not find that the construction of the nation is a negative process, but that is a necessary element in our society. Alternatively to Anderson, Gellner, a constructionist theorist, argues that the nation overwhelms local cultures and prevents people from being completely free (Kearney, 2007).

6 Very often nations produce culture, importantly for this article. National culture has long been defined through functionalist and constructivist lenses. The first perspective pointed out by Kluckhohn (1951) and Kroeber and Parsons (1958) define national culture as a whole of values shared within a community, not socially constructed but natural and innate. Following on from this, Hofstede (1980) argues that the state is the place in which we may best study various forms of culture. Hofstede later modified his theory and found that cultures are more complex systems, always in a state of flux (Wong, 2008). The constructivist approach, conversely, investigates national culture as constructed through a negotiation between culture (and therefore also the media), politics and the economy. Gramsci (1964), Hall (1992) and Edensor (2002) state these principles, and their points of view are developed in the theoretical framework below.

\section{Nation, TV and food}

7 Both TV and food have very often been analysed as sources of feelings of national identity and as elements helping processes of nation building. As regards TV, and the media in general, back in the 1920s Lippmann theorised that images of the nation were in people's minds and that stereotypes marked the difference between the "world outside and the pictures in our heads" $(2004, \mathrm{p}$. 1$)$. When television was still in its first years, scholars focused on newspapers as the most popular sites of images of the nation 
(Larson \& Rivenburgh, 1991). When radio and television rose, the so-called mass media became in many studies the main sources of national identity and nationalism (Deutsch, 1953). From a constructivist point of view, television and the other media are seen as producers of 'versions' of the nation, socially constructed representations of the nation-state (Hall, 1992; Johnson, 1993; Wodak, De Cillia, Reisigl \& Liebhart, 2009).

Many studies centre on the way television and the other media boost sentiments of national identity. For Porto (2011), telenovelas shape national identity in Brazil through the representation of characters, emotions and landscapes. Globalisation has sometimes been seen as contrasting with nationality, and Castellò, Dhoest and O'Donnell (2009) advance that TV mostly supports national interests. However, echoing Hall, Larson and Rivenburgh (1991) point out that TV has both aims, representing the local as home and the global as a potential otherness.

In terms of the relationships between the nation and food, Appadurai (1988) investigates Indian cookbooks as the basis of Indian food culture, finding that these books acquire a fundamental social role by trespassing divisions that other Indian social constructions strictly respect. In line with cultural studies, which is part of the theoretical framework of this article, Appadurai states that this construction has hegemonic and economic goals, as "the publishing industry, catering industry, food industries, and the commercial sector in agriculture all have something to gain from the new culinary developments in Indian cities" (1988, p. 10).

Heldke $(2003,2005)$ starts from the fact that national food culture is always a socially constructed concept and focuses on how nations tend to confer notions of authenticity on their foods to reinforce themselves and exploit the Other. Finally, Wilk (2002) analyses an example demonstrating the constructive nature of food culture, the case of Belizean cuisine. A Belizean cuisine actually did not exist in Belize, but it was created by the Belizean immigrants who opened restaurants and food shops in many US cities. When these immigrants went back home, they took 'their' Belizean cuisine, unknown to the people who had not moved from Belize.

11 Back et al. (2012) point out that paradoxically globalisation supports the local and creates invented traditions regarding food. These invented traditional foods serve the purpose of reassuring those who are displaced in the globalised world. Clearly, these products actually have nothing to do with traditions but are the result of industrial and globalised production processes.

\section{The case of Scotland}

There are certainly many issues involved when analysing national identities in Britain, where four 'nations' or ethnic groups (England, Scotland, Wales and Northern Ireland) coexist in one state (the UK) (Naim, 1988). Olwig (2008) argues that in Britain there are actually three nations (England, Scotland, and Wales) but that only one, England, is the real leader. To hide the problem of the co-existence of various groups within the same territory, the nation is often represented as the result of natural processes. For example its being an island helps underline its natural origins and cover uncomfortable political discrepancies. Thus, depicting Britain as a natural entity reinforces the idea of it as a nation.

13 Johnson (1993) argues that Englishness is based on a precise English accent, multiethnic cuisine and rural landscapes and foods. Brennan (1990) advances that immigration to 
England after WWII changed the essence of being English, extending the concept to multiethnic groups. Greenfeld (1992) points out that English nationalism has always been democratic, and this has made it different from that in Germany or Italy, which was based on dictatorships. Easthope (1999) says that today's English identity comes from the English empiricism of the seventeenth century. Kumar (2003) criticises the fact that British identity has continuously been built on oppositions such as Britishness vs Scottishness or Britishness vs Englishness, while for example in India this has never happened.

On Scotland's identity, Kumar (2003) sees Scottishness as the result of the combination of its different powers, from the Scottish Parliament to its religion and its independent law. Hearn (2000) also finds Scottish identity as a result of a combination, but composed of historical heritage and class peculiarities, partly British, partly Celtic, European, Western, working class, and so on. Finally, Davidson (2000) argues that Scottishness is recognisable as a part of Britishness, and that Britishness will never be the same when Scotland is no longer a part of it.

\section{Useful theories}

15 This article draws on cultural studies theories regarding the nation and the media and analysing food and TV as sources of national culture and identity. Hall finds that "three resonant concepts [...] [form] a national culture as an imagined community: memories from the past; the desire to live together; the perpetuation of the heritage" (1992, p. 296). He profoundly supports the idea that the nation is a social construction and that national cultures promoted by the media reinforce national identities.

Once a nation has been formed, the process of nation-building does not cease, but goes on to reinforce national identity (Gross, 2009). Relevantly for this article, Bhabha (1990) and Berger (2011) argue that the nation and national cultures are forms of narration, thus like the media they have "textual strategies, metaphoric displacements, sub-texts and figurative stratagems" (Bhabha, 1990, p. 2). For Hall, like a medium, "a nation [...] produces meanings-a system of cultural representation" (1992, p. 292); rather than an imagined community, therefore, "a nation is a symbolic community" (ibid.).

Related to this, Billig (1995) underlines that media and popular culture in general support the nation through 'weak' forms of representation of the national. These forms are mainly present in popular culture and are far from being 'strong' as the political manifestations of nationalism; however, they manage to create long-lasting feelings of national belonging. Edensor (2002) theorises that some of these representations regard the landscape, which is really powerful in building a solid idea of nation thanks to its iconic and ancestral character.

Specifically on TV, Morley (2004a, 2004b) see this medium as central to both home and the nation. In fact, as a bigger home, national broadcasting can create a sense of unity under the nation and secure its cultural boundaries (Morley, 2004b). However, this process involves members of the audience in complex power relationships (Morley, 2004a). Buscemi (2014) shows how, on national food travelogues on Italian and British TV, food and the nation brand each other in a win-win relationship.

As regards food, Belasco argues that in relation to the nation, "food means power, power means food" (2002, p. 4), Similarly, Appadurai (1988) points out that national 
food cultures are constructed through processes helping the interests of politics and economics.

\section{Methods}

The article applies multimodal analysis to moving image items regarding the haggis as it is represented on cooking shows on both television and the internet. Multimodal analysis is the research method which decomposes media messages into different modes. Each mode is analysed per se and later the various results are combined in order to reach more general conclusions (Taylor, 2014). Modes may regard image (colours, shapes, non verbal language, camera angles, etc.); words (spoken language, writings, etc.); sounds (music, noises, etc.) and other elements. Bezemer (2012) argues that multimodal analysis specifically fits the analysis of moving image items. Moreover, he underlines that modes are to be analysed in the context of their relationships to what happens in the corresponding society, as modes both affect and are affected by culture, politics and social phenomena.

Jewitt (2014) sees three kinds of multimodal analysis: a social semiotic one, following on from Hodge and Kress (2008), and Kress and van Leeuwen (2001); a functional grammar multimodal approach, created by O'Toole (1994) and O'Halloran (2004); and an interactional version of this research method, focusing on spoken language and referring to Norris (2004). This article relates to the social semiotic strand, as its aim is to analyse the social and cultural elements recurring in the representation of the haggis as a national symbol.

In terms of sampling, this article applies qualitative purposive sampling, "a nonrandom sampling technique in which the researcher selects elements supporting a particular theory or presenting specific characteristics" (Buscemi, 2015, p. 127). Drawing on this sampling strategy, this article has selected the representations of the haggis in moving image items containing references to Scotland, Scottish culture and Scottish identity.

\section{The analysis}

\section{The haggis and the ancestral nation}

It is very interesting to note that almost each celebrity chef who has visited Scotland has felt obliged to deal with the haggis, either respecting tradition or innovating with it. The first interesting case is in Jamie's Great Britain (Oliver, 2011), a food travelogue where Jamie Oliver goes around the entirety of Britain in search of good British food. Episode 6, the last of the series, is entirely dedicated to Scotland. At the beginning, Oliver visits what he terms as the oldest restaurant in Glasgow, where he prepares the haggis, cooked as tradition wants with the addition of Indian spices to see how this dish is reinvented in a multiethnic city. The national identity links present in this scene have already been highlighted in Buscemi (2018), however, what is important to underline here is the way the show portrays the preparation of the dish.

The visual mode here is the most relevant. At the beginning of the preparation we can see in fact the whole dead animal on the kitchen table, followed by the local chef 
cutting it into pieces and pulling its inner organs out. Oliver underlines the unusual image, at least on TV, by defining the preparation as a sort of autopsy. For him, this happens because the haggis is an ancestral dish, created by the Vikings and permeating the entire Scottish history. In the second part of the preparation, Oliver cuts kidneys, liver and other internal organs into even smaller pieces and puts them in a pan, while explaining that the poor origins of this dish were only later adopted by the rich. The restaurant owner concludes by defining the haggis a "national dish".

It is interesting how Oliver (2011) here combines different elements all leading to the concept of the ancestral: the fact that the preparation is set in the oldest restaurant in Glasgow links the entire scene to the remote past, tradition, and the very beginning of Scottish food culture; the crude images of the dead animal and its organs, really unusual in Oliver's shows and on TV in general, adds the idea of a crude Scottish nature, also underlined in other parts of the show, such as the hunt with scenes of animal killing and the fishing with the hard work of the fishermen. Thus, the haggis becomes a part of a wider idea of Scotland, where a primordial form of nature is to be dominated by the humans and their culture by violence and killing.

This ancestral character of the haggis is confirmed in The Tale of the Wild Haggis (VisitScotland, 2014), a fictional story regarding an imaginary animal, the haggis, which would be the source of the dish. The official website of the Scottish tourism office VisitScotland presents a video telling the story of this mysterious animal (VisitScotland, 2014). Apart from the other details about this strange creature, it is interesting to note how in the video the ancestral character of the animal is intrinsically bound to the ancestral nature of Scotland. The story of the animal in fact starts "in the mist of time", is "full of mystery" and has happened in a place, Scotland, of "wild land and wild life".

The animal may be found all over Scotland, and this means that it regards the entire nation, is somehow a common trait of the entire country. According to the video, the animal lives in the wilderness of Scotland but it ends up being at the heart of the celebrations of the Burns night. The second part of the video, in fact, depicts the haggis as an item of food, and explains how it is important throughout Scottish history starting from Robert Burns and his poem specially made for the dish.

In the video it is the tone of voice of the speaker which confers this mysterious and ancestral aura. The words that the speaker says are solemn as his voice, and the tone seems to come from a remote past. Images are conversely more explicit, depicting the animal, a sort of hedgehog which has nothing has to do with lambs and sheep, the animals really involved in the preparation of the haggis. This certainly detaches the animal from the food. Depicting a non-existent animal, in fact, softens the idea that by eating the haggis people are actually eating a dead animal. In this case, however, the imaginary animal importantly also adds something else to the tone of mystery that has been underlined above. Being a non-existent living being, in fact, it communicates a sense of unreality. Finally, a third mode, music, adds to the chronological detachment from the present, being the music an ancient medieval melody.

Finally, another video underlines the close relationships between the haggis and tough nature. It is one of the videos of the YouTube channel Munchies, a channel which shows food recipes to its more than three million members. Munchies is the food section of the global magazine Vice, which has twenty-nine national editions worldwide. The video on the haggis explains Burns' poem, underlining "the honest face" and the 
"integrity" of this dish and focusing on the image of "the knife being pulled out and stabbed into the haggis ripped apart like the entrails of a beast coming out" (Munchies, 2014). Again, crude nature is the ideal atmosphere surrounding this dish. This tough scenario is the link between the dish and the nation that it represents, Scotland. The haggis thus prefigures an archaic land of mystery and tough nature, still non-civilised and where humans must cope with an inhospitable nature.

\section{The haggis as a Scottish identity food}

Apart from this almost archaic representation of the haggis, other cooking shows and videos offer other correlations between the haggis and Scotland. The Hairy Bikers give the haggis a more social function, however always relating to a precise idea of national identity. In The Hairy Bikers: Mums Know Best (Hairy Bikers, 2011), homage to home cooking in Britain, the two motorcycle riding cooks visit Scotland and specifically Camila's home in Dundee. Camila is of Yemenite origins, concerned with her family traditions but also wishing to feel Scottish. To do so, in order to prepare something to eat for her relatives who are from Yemen, she cooks haggis samosa, that is, the perfect mix between the most Yemenite and the most Scottish food. Samosas are in fact small fried (sometimes baked) pastries usually filled with either meat or vegetables, one of the most traditional Yemenite (and generally Asian) dishes. However, as Camila says, at her home Samosas have undertaken a Scottish twist, being filled with the haggis.

Even in this case, the visual mode underlines the relevance of the haggis in terms of nationality. The lunch at Camila's home is warm and welcoming, with the Yemenite people mediating between their tradition and new culture by eating haggis samosa. Actually, what they (and we) see is samosa; however, inside the samosa is the haggis, the ingredient which makes Camila at least half Scottish. For her, the haggis is a sort of Scottish passport, it is in fact thanks to it that she can feel a Scottish citizen. Importantly, haggis samosa is also prepared in Madhur Jaffrey's Curry Nation (Jaffrey, 2012), a cooking show by the Indian food expert Jaffrey, where a group of Indians who emigrated to England want to mediate the two food cultures and adopt the new one without forgetting the first.

Importantly, Camila has not prepared the haggis, but she has bought it already made. It would have been exaggerated to make this further step. In watching celebrity chefs' episodes regarding this dish, in fact, it seems that cooking the haggis is an ability generally left to real Scottish people, while those who come from abroad may only eat and appreciate it, or cook it with a lesser degree of Scottishness. The haggis, in the two episodes that are analysed below, seems to be a dish able to measure how much Scottishness there is inside a person.

This is exactly what happens to Gordon Ramsay when he challenges the Scottish radio and TV presenter Edith Bowman in cooking haggis (Ramsay, 2008). Ramsay is an internationally renowned chef, more precisely the world's third most decorated Michelin star chef: his restaurants have in fact been awarded sixteen Michelin stars, following Joël Robuchon with thirty-one stars and Alain Ducasse with twenty-one (Tessendorf, 2018). Many critiques have been raised of Ramsay as a TV personality and of his impolite way in treating wannabe chefs, but certainly his ability as a chef is undoubted. The fact that he challenges a non-chef is certainly unusual on mainstream 
cooking shows. A celebrated chef, in fact, would easily win without any thrilling uncertainty and the necessary suspense of the match would simply disappear.

In spite of all of this, the two personalities compete in cooking the haggis. Incidentally, Ramsay was born in Scotland but grew up in England and soon became a global chef; Bowman, his competitor, is instead deeply Scottish, and even graduated at a Scottish university. Moreover, she has frequently presented shows for BBC Scotland, many editions of the Young Scot Awards and other shows relating to Scotland. Even though she has never declared what she voted at the referendum on Scottish independence, the day of the vote she wrote a 'proud' tweet talking about Scotland as a nation and the Scots as a race: "Good luck today my fellow country folk. Whatever the result we are a proud nation, an inspiring race. Be respectful of each other's choices." (Creed, 2014)

The match starts: the third best chef in the world and the DJ and TV presenter cook their respective versions of the haggis. If, as has been said above, the match between two such different personalities is unusual, the result is even more surprising. Bowman wins 5 to 0 . The sequence seems to say that only a real Scot may cook a good haggis. Being a half Scot may allow you to prepare it, but noy to defeat the same dish prepared by a 100 percent Scotland native, even though you are one of the best chefs in the world. Thus, to cook the haggis very well, you do not have to be a starred chef, you must be Scottish. It may appear strange, but in cooking this dish the knowledge of cooking techniques, years of study and practice, and international awards are less decisive than your national identity.

The same feeling of national identity is well visible in another show where Gordon Ramsay faces the haggis. It is the American edition of MasterChef (Ramsay, 2014), where Ramsay is one of the members of the jury, along with Joe Bastianich and Elliot Smith. They have to judge a Scottish contestant who has prepared the haggis, in this case enriched with external and new ingredients. Ramsay compliments the contestant for the courage she demonstrates in taking the haggis to Los Angeles. While Elliot seems to be moderately convinced by the experiment, the two opposite positions are represented by Bastianich and Ramsay.

The second immediately declares his Scottishness while Bastianich suggests not exaggerating with this "paesano" approach. An important moment is when Ramsay somehow challenges Bastianich asking the contestant to list the ingredients of the haggis. She starts saying all the inner parts of the lamb contained in the dish, and the camera focuses on Bastianich's face, more disgusted at each ingredient added to the list. Bastianich says that he is Italian, but the contrast between Italianness and offal is an invention of the programme. Italian cuisine has in fact always contemplated dishes made up of the inner organs of the animal (Riley, 2007, pp.346-7). However, the narrative of the show is constructed around this contrast. In the end, Bastianich says that he is Italian and cannot appreciate the haggis, Elliot says yes and Ramsay approves the dish, saying that tasting that haggis made him feel homesick. Ramsay's response is decisive, and thanks to his "yes" the contestant continues the tournament.

In this scene there are two interesting elements linked to the content of this article. The first one regards the language of the show. In MasterChef, the visual mode is usually adopted to depict the sumptuous aspect and aesthetic beauty of the dishes and the reaction of the faces of people who eat them. In this case, only the second strategy is chosen, as we do not see the haggis in detail as other dishes. Bastianich's face, conversely, is visually highlighted because of his reactions to the list of the ingredients. 
Importantly, even the verbal mode follows this trend. The three chefs and the contestant do not talk about the quality of the dish in depth, its taste and the level and technique of the preparation, as they do in other cases. Here they mostly talk about being Italian and being Scottish. Nationality and national identity are thus the lenses through which the dish is examined and assessed.

Related to this, the second element is the fact that the match becomes a matter of nationality. An Italian chef or person cannot understand the haggis, even though this is based on a false presumption, the fact that an Italian is not used to dishes composed of the inner parts of the animal. A Scot, instead, may fully enjoy the haggis, and if they are abroad, it makes them feel homesick.

\section{Conclusion}

As we have seen in the analysis, there are two wide strands of representation of the haggis. The first mostly pertains to its ancestral origins and to its links to a tough version of nature, inhospitable landscapes and animal death, always relating to Scotland. As underlined in the theoretical framework of this article by Hall (1992), the recurring representation of the past is of paramount importance to promote the nation, and these representations, from Oliver's show to the VisitScotland (2014) video, adopt the past in order to build a more solid idea of the nation, even though, as is explained below, they refer to two different nations.

In the case of Jamie Oliver (2011), the haggis is visually connected to the dead animal, a form of representation which is very unusual on TV. This must be linked to the general image that Scotland has on Oliver's (2011) show Jamie's Great Britain, a place where nature is harsh and hostile to humans, a powerful representation of landscape which reinforces the idea of the nation, as theorised by Edensor (2002). In the show this place is opposed to England, which is instead the land of the Industrial Revolution and of civilisation. The haggis, with its inner organs coming up from the open animal, is seen as perfectly in line with Scotland and its "mist of the time", as in the Munchies video, which underlines blood and violence as the hidden ingredients of the dish.

In Oliver's (2011) show, however, England and Scotland (with Wales and Northern Ireland) all contribute to the same nation, the UK. Conversely, in the VisitScotland (2014) video, the UK is never mentioned and the nation to be promoted is exclusively Scotland. This moves the focal point of the narration of the nation as Scotland is turned from one of the co-protagonists to the undiscussed main character.

The second strand regards the social links between this dish and the Scottish nation and identity. In this second group of visual representations (Ramsay, 2008, 2014; The Hairy Bikers, 2011), in fact, the haggis is seen as a sort of passport to feel Scottish and a dish measuring the degree of Scottishness in a person. The dish is depicted through interesting visual and textual strategies which reinforce its links to the concepts of the nation and national identities. In this regard, there is an element that has emerged throughout the analysis and that is important to examine here, because it is new in comparison to the other analyses which have been reviewed at the beginning of this article: it is the global character of the haggis, its being frequently mixed up with ethnic foods or ingredients which are extraneous to its tradition. 
haggis as a social weapon, an instrument which can bridge ethnic gaps or demonstrate
and increase the degree of Scottishness, All of these elements thus may be considered
representations pertaining to banal nationalism (Billig, 1995) which narratively (Bhabha, 1990; Berger, 2011) construct Scotland as a credible nation. A nation with a common culture, able to communicate with other nations, to produce meaning and to create a symbolic community of citizens (Hall, 1992). 


\section{BIBLIOGRAPHY}

ANDERSON Benedict, 1983, Imagined Communities: Reflections on the Origin and Spread of Nationalism, London, Verso.

APPADURA Arjun, 1988, "How to Make a National Cuisine: Cookbooks in Contemporary India", Contemporary Studies in Society and History, vol. 30, no. 1, pp. 3-24.

BACK Less, BenNETT Andy, EdLes Laura Desfor, GiBson Margaret, Inglis David, JACobs Ron \& WOODWARD Ian, 2012, Cultural Sociology: An Introduction, Chichester, Wiley-Blackwell.

BALIC Adam, 2013, “The Haggis", in M. MacWilliams (ed.), Wrapped and Stuffed Foods: Proceedings of the Oxford Symposium on Food and Cookery 2012, London, Prospect Books, pp. 82-93.

BELAsco Warren, 2002, "Food Matters: Perspectives on an Emerging Field”, in W. Belasco and P. Scranton (eds), Food Nations: Selling Taste in Consumer Societies, New York, Routledge, pp. 2-23. BEZEMER Jeff, 2012 (16 February), “What Is Multimodality?', University College London. Available on <https://mode.ioe.ac.uk/2012/02/16/what-is-multimodality/>.

BERGER Stefan, 2011, "Introduction: Narrating the Nation", in S. Berger, L. Eriksonas and A. Micock (eds), Narrating the Nation: Representations in History, Media and the Art, New York, Berghahn Books, pp. 1-16.

BHABHA Horny K., 1990, "Introduction: Narrating the Nation", in H. K. Bhabha (ed.), Nation and Narration, London, Routledge, pp. 1-7.

BILLIG Micheal, 1995, Banal Nationalism, London, Sage.

BRENNAN Timothy, 1990, “The National Longing for Form”, in H. K. Bhabha (ed.), Nation and Narration, London, Routledge, pp. 44-70.

BURNs Robert, 1850, The Works of Robert Burns, London, Henry G. Bohn publisher.

BusCEMI Francesco, 2014, “Jamie Oliver and the Gastrodiplomacy of Simulacra”, Public Diplomacy Magazine, no. 11 (special issue Gastrodiplomacy), pp. 46-50.

BUSCEMI Francesco, 2015, “How ‘Il Caffè Sospeso' Became 'Suspended Coffee': The Neo-Liberal Re-'Invention of Tradition' from Bourdieu to Bourdieu”, European Journal of American Culture, vol. 34, no. 2, pp. 123-36.

BUSCEMI Francesco, 2018, “The Ancestral Room of the State? Scotland and the UK on Jamie's Great Britain”, Journal of Communication Inquiry, vol. 42, no. 3, pp. 258-74.

CASTellò Enric, Dhoest Alexander \& O’Donnell Hugh, 2009, “Introduction”, in E. Castellò,

A. Dhoest and H. O'Donnell (eds), The Nation on Screen: Discourses of the National on Global Television, Newcastle, Cambridge Scholars, pp. 1-9.

CREED Barry, 2014 (18 September), “Tweets from Famous Scottish Folk on Referendum Day”, The Irish Times. Available on <www.irishtimes.com/news/world/uk/tweets-from-famous-scottishfolk-on-referendum-day-1.1933618>.

CROFTON Ian, 2014, A Curious History of Food and Drink, London, Quercus.

DAVIDSON Neil, 2000, The Origins of Scottish Nationhood, London, Pluto Press. 
DeUTSCH Karl W., 1953, Nationalism and Social Communication: An Inquiry into the Foundations of Nationality, New York, John Wiley \& Sons.

EASTHOPE Anthony, 1999, Englishness and National Culture, London, Routledge.

EDENSOR Tim, 2002, National Identity, Popular Culture and Everyday Life, London, Berg.

GRAMSCI Antonio 1964, Quaderni dal Carcere: Letteratura e Vita Nazionale, Torino, Einaudi editore.

GREENFIELD Liah, 1992, Nationalism: Five Roads to Modernity, Cambridge (MA), Harvard University Press.

GRoss Bernhard, 2009, “Locating Britain: Migration and Shifting Boundaries on TV News", in E. Castellò, A. Dhoest and H. O'Donnell (eds), The Nation on Screen: Discourses of the National on Global Television, Newcastle, Cambridge Scholars, pp. 139-55.

GuiBERnAu Montserrat, 2007, The Identity of Nations, Cambridge, Polity Press.

HALL Stuart, 1992, “The Question of Cultural Identity”, in S. Hall, D. Held and T. McGrew (eds), Modernity and Its Futures, Cambridge, Polity Press-The Open University, pp. 273-316.

HEARN Jonathan, 2000, Claiming Scotland: National Identity and Liberal Culture, Edinburgh, Polygon.

HELDKE Lisa M., 2003, Exotic Appetites: Ruminations of a Food Adventurer, New York, Routledge.

HELDKE Lisa M., 2005, "But Is It Authentic? Culinary Travel and the Search for the 'Genuine Article”', in C. Korsmeyer (ed.), The Taste Culture Reader, Oxford, Berg, pp. 385-94.

HODGE Robert \& KRESS Gunther, 1988, Social Semiotics, Cambridge, Polity Press.

HOFSTEDE Geert, 1980, Cultural Consequences: International Differences in Work-Related Values, London, Sage.

JAFFREY Madhur, 2012, Madhur Jaffrey's Curry Nation, TV programme, London, BBC Good Food. JewitT Carey, 2014, “Different Approaches to Multimodality”, in C Jewitt (ed.), The Routledge Handbook of Multimodal Analysis, London, Routledge, pp. 31-43.

JoHnson Richard, 1993, “Towards a Cultural Theory of the Nation: A British-Dutch Dialogue”, in A. Galema, B. Henkes and H. Te Velde (eds), Images of the Nation: Different Meaning of Dutchness, 1870-1940, Amsterdam, Rodopi, pp. 159-218.

KeARNEY Kirsten, 2007, Constructing the Nation: The Role of the Ballad in Twentieth Century German National Identity with Special Reference to Scotland, $\mathrm{PhD}$ thesis, University of Stirling.

KLucкнонn Còyde, 1951, “The Study of Culture”, in D. Lerner and H. D. Lasswell (eds), The Policy Sciences, Stanford, Stanford University Press, pp. 86-101.

KRESS Gunther \& VAN LEEUWEN Theo, 2001, Multimodal Discourse: The Modes and Media of Contemporary Communication, Oxford, Oxford University Press.

KROEBER Alfred \& PARSON Talcott, 1958, "The Concepts of Culture and of Social Systems", American Sociological Review, vol. 23, no. 2, pp. 582-3.

KUMAR Krishan, 2003, The Making of English National Identity, Cambridge, Cambridge University Press.

LARSON James F. \& RIVENBURGH Nancy K., 1991, “A Comparative Analysis of Australian, US and British Telecasts of the Seul Olympic Opening Ceremony”, Journal of Broadcasting \& Electronic Media, vol. 35, no. 1, pp. 75-94. 
LiPPMANN Walter, 2004, Public Opinion, Mineola (NY), Dover.

MEINECKE Friedrich, 1970, Cosmopolitanism and the National State, translated from the German by R. B. Kimber, Princeton, Princeton University Press.

MORLEY David, 2004a, "Broadcasting and the Construction of the National Family", in R. C. Allen and A. Hill (eds), The Television Studies Reader, London, Routledge, pp. 418-41.

MORLEY David, 2004b, “At Home with Television”, in L. Spigel and J. Olsson (eds), Television After TV: Essays on a Medium in Transition, Durham (NC), Duke University Press, pp. 303-23.

MUNCHIES, 2014, How to Make Haggis, video, London, Munchies. Available on <https://youtu.be/ MuEmB7frgTI>.

NAIM Tom, 1988, The Enchanted Glass: Britain and Its Monarchy, London, Radius.

NoRRIS Sigrid, 2004, Analyzing Multimodal Interaction: A Methodological Framework, London, Routledge.

O’Halloran Kay (ed.), 2004, Multimodal Discourse Analysis: Systemic Functional Perspectives, London, Continuum.

O’Toole Michael, 1994, The Language of Displayed Art, Leicester, Leicester University Press.

OLIVER Jamie, 2011, Jamie's Great Britain, TV programme, London, Channel 4.

OLWIG Kenneth R., 2008, “Natural' Landscapes in the Representation of National Identity”, in B. J. Graham and P. Howard (eds), The Ashgate Research Companion to Heritage and Identity, Aldershot, Ashgate, pp. 73-88.

PORTO Mauro 2011, "Telenovelas and Representations of National Identities in Brazil”, Media Culture and Society, vol. 33, no. 1, pp. 53-69.

RAMSAY Gordon, 2008, The F Word, TV programme, London, Channel 4.

RAMSAY Gordon, 2014, MasterChef, TV programme, Los Angeles, Fox Network.

RILEY Gillian, 2007, The Oxford Companion to Italian Food, New York, Oxford University Press.

SMITH Anthony D., 2010, Nationalism, Cambridge, Polity Press.

TAYLOR Roberta, 2014, "Multimodal Analysis of the Textual Function in Children's Face-to-Face Classroom Interaction", in A. Maiorani and C. Christie (eds), Multimodal Epistemologies: Towards an Integrated Framework, New York, Routledge, pp. 228-44.

TEsSENDORF Kim, 2018, “The World's Most Decorated Micheline Star Chefs", Truly Experience. Available on <https://trulyexperiences.com/blog/decorated-michelin-star-chefs-still-business/>. THE HAIRY BIKERS, 2011, Hairy Bikers' Mums Know Best, TV programme, London, BBC.

VisitScotLAND, 2014, The Tale of the Wild Haggis, video, Edinburgh, VisitScotland. Available on <https://youtu.be/DuLbbXGFG50>.

WILK Richard, 2002, "Food and Nationalism: The Origins of 'Belizean Food”, in W. Belasco and P. Scranton (eds), Food Nations: Selling Taste in Consumer Societies, New York, Routledge, pp. 67-89. WODAK Ruth, De CILLIA Rudolf, REISIGL Martin \& LIEBHART Karin, 2009, The Discursive Construction of National Identity, Edinburgh, Edinburgh University Press. 
WONG Loong, 2008, "Culture and Corporate Governance: Revisiting the Cultural Imperative", in G. Aras and D. Crowther (eds), Culture and Corporate Governance, Leicester, Social Responsibility Research Network, pp. 149-77.

\section{ABSTRACTS}

This article aims to analyse the way television has created or recirculated the haggis as the Scottish national dish. It draws on cultural studies analyses of food and TV as sources of nation building, Appadurai's account of the construction of a national cuisine and Belasco's insight into the way national food cultures are created for political reasons. The article textually, visually and symbolically analyses accounts of the Scottish haggis constructed by celebrity chefs such as Jamie Oliver, the Hairy Bikers and Gordon Ramsay, and by videos on the web.

The results show that the haggis is represented in two ways: on the one hand, it contributes to constructing Scotland as an ancestral nation based on tough nature; on the other hand, the dish is depicted as a tool for measuring the degree of Scottishness of people or as a passport which allows people coming from other countries to feel more Scottish.

INDEX

Keywords: haggis, food TV, Scotland, national identity, UK

\section{AUTHOR}

\section{FRANCESCO BUSCEMI}

Catholic University of Milan 